\title{
Retraction Note: Atmospheric environmental impact and communication signal processing optimization in coastal areas
}

Lei $\mathrm{Li}^{1,2} \cdot$ Ling $\mathrm{Li}^{3}$

Published online: 30 November 2021

(c) Saudi Society for Geosciences 2021

Retraction Note: Arabian Journal of Geosciences (2021) 14: 896 https://doi.org/10.1007/s12517-021-07206-z

The Editor-in-Chief and the Publisher have retracted this article because the content of this article is nonsensical. The peer review process was not carried out in accordance with the Publisher's peer review policy. The authors have not responded to correspondence regarding this retraction.

The original article can be found online at https://doi.org/10.1007/ s12517-021-07206-z.

Lei Li

sherry8188@126.com

1 Key Laboratory of Media Audio \& Video (Ministry of Education), Communication University of China, Beijing 100024, China

2 Communication University of Shanxi, Jinzhong 030619, Shanxi, China

3 Xinyu University, Xinyu 338004, Jiangxi, China 